\title{
The Effects of Ultra Sound Waves on Serum Levels of AST and ALT in Male Rats
}

\author{
Kheyrvari J, Ahmadi R, Moradi Sh
}

\begin{abstract}
Serum levels of various biochemical enzymes including SGOT and SGPT are influenced by environmental factors. The main aim of this study was to determine the effects of ultrasound waves on serum levels of SGOT and SGPT in male rats. In our study male Wistar rats were randomly divided into control and groups exposed to ultrasonic waves for 1, 6h/day. After 8 weeks, blood samples were obtained using cardiac puncture methodA. Following serum preparation, level of enzymes was measured using spectrophotometry method. Data were statistically analyzed and compared between groups using ANOVA. The results indicated that serum level of SGOT did not significantly change in animals exposed to ultra wave sounds compared to control animals; however, serum level of SGPT significantly decreased in rats exposed to ultra wave sounds for $6 \mathrm{~h} /$ day compared to control animals.
\end{abstract}

\section{Keywords - SGOT, SGPT, Ultra Wave Sound, Rat.}

\section{INTRODUCTION}

$\mathrm{U}$ LTRASOUND is acoustic (sound) energy in the form of waves having a frequency above 20 thousand cycles per second $(20,000 \mathrm{~Hz})$.Ultrasound is used in medicine to view internal organs of the body, electronic, navigational, industrial, and security applications.

Aspartate transaminase (AST) or aspartate aminotransferase, also known as AspAT/ASAT/AAT or serum glutamic oxaloacetic transaminase (SGOT), is a pyridoxal phosphate (PLP)-dependent transaminase enzyme .[1] AST catalyzes the reversible transfer of an $\alpha$-amino group between aspartate and glutamate and, as such, is an important enzyme in amino acid metabolism.[2] AST is found in the liver, heart, skeletal muscle, kidneys, brain, and red blood cells.[3]

Alanine transaminase (ALT) is also called alanine aminotransferase (ALAT) and was formerly called serum glutamate-pyruvate transaminase (SGPT) or serum glutamic-pyruvic transaminase (SGPT).[ 4] ALT is found in plasma and in various body tissues, but is most common in the liver.[5] It catalyzes the two parts of the alanine cycle. Serum ALT level, serum AST (aspartate transaminase) level, and their ratio (AST/ALT ratio) are commonly measured

clinically as biomarkers for liver health.

Most of the studies documented that noise significantly increases the likelihood of hypertension [6] and plasma cortisol level in rat [7] and fishes [8]. It is believed that noise exposure induce oxidative stress in rat [9] and can affect on brain neurotransmitters. [10],[11] There are reports also

Jamil Kheyrvari Khezerloo is with Department of Biochemistry, Faculty of Advanced Sciences \& Technology, Pharmaceutical Sciences Branch, Islamic Azad University, Tehran-Iran (IAUPS).

Rahim Ahmadi (PhD) is with the Department of Physiology, Faculty of Basic Sciences, Islamic Azad University, Hamedan Branch, Hamedan, Iran.

Shohreh Moradi (MSc) is with the Department of Physiology, Faculty of Basic Sciences, Islamic Azad University, Hamedan Branch, Hamedan, Iran. indicating that exposure to noise pollution has negative effects on male reproductive system. [12]

In this study we aimed to determine the effects of ultra wave sounds on serum levels of ALT and AST in male rats.

\section{MATERIAL AND METHODS}

\section{A. Animals}

Adult Wistar male rats weighting $190 \pm 10 \mathrm{~g}$ were purchased and raised in our colony. The temperature was at $22 \pm 2 \mathrm{C}$ and animals kept under a schedule of $12 \mathrm{~h}$ light: $12 \mathrm{~h}$ darkness (light on at 08:00 a.m.) with free access to water and standard laboratory chow. Weight averages of every cage kept in same weight and eliminated weight factor.

\section{B. B. Protocol of Study}

Male wistar rats were divided by into control and groups exposed to ultrasonic waves for $1,6 \mathrm{~h} /$ day. After 8 weeks blood samples were obtained using cardiac puncture method. Following serum preparation, level of enzymes were measured using spectrophotometry method.

\section{Statistical Analysis}

All Values are presented as mean \pm S.E.M. Statistical significance was evaluated by one-way analysis of variance (ANOVA, Student t-test) using SPSS 19. Differences with $\mathrm{P}<0.05$ were considered significant.

\section{RESUltS}

Figure I and II show serum levels of ALT (SGPT) and AST (SGOT) in male rats exposed to ultra wave sound.

Our findings show that serum level of AST did not significantly change in animals exposed to ultra wave sounds compared to control animals; however, serum level of ALT significantly decreased in rats exposed to ultra wave sounds for $6 \mathrm{~h} /$ day compared to control animals.

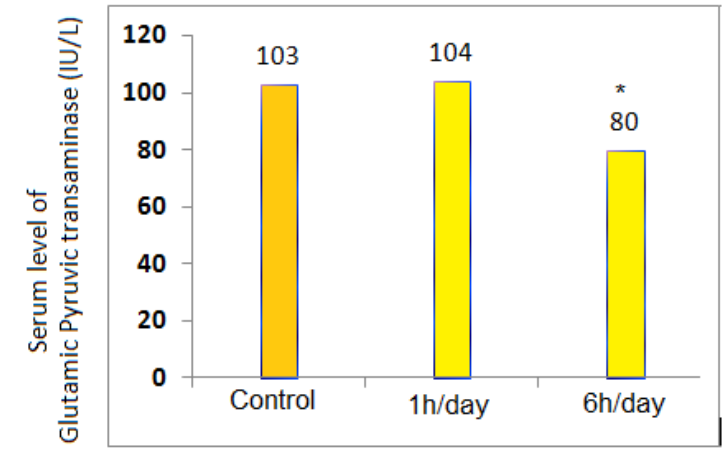

Fig I. Serum levels of ALT (SGPT) in rats exposed to ultra wave sounds for $1 \mathrm{~h} /$ day and $6 \mathrm{~h} /$ day. 


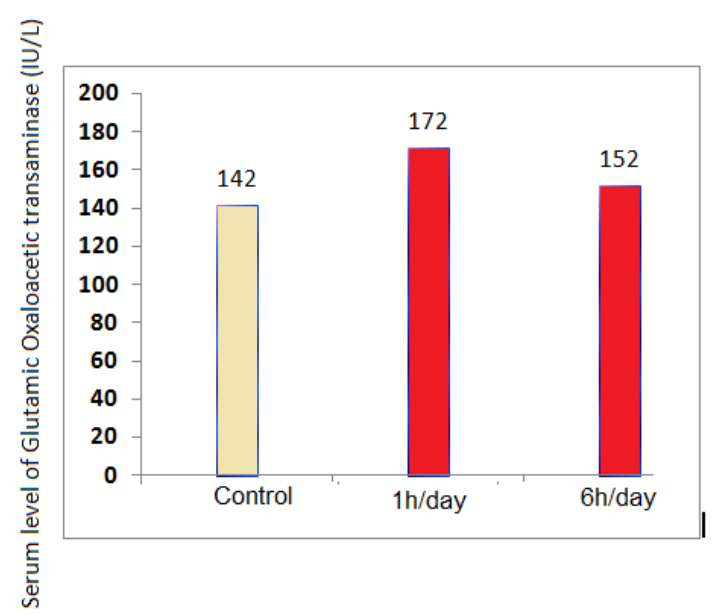

Fig II. Serum levels of AST (SGOT) in rats exposed to ultra wave sounds for $1 \mathrm{~h} /$ day and $6 \mathrm{~h} /$ day.

\section{DISCUSSION}

We have shown that exposure to ultra wave sounds results in decreased serum levels of SGPT indicating that exposure to ultra wave sounds particularly for a long period of time may adversely influence heart and/or liver function or structure and/or other tissues. In line with our finding there are also other records indicating that serum levels of some enzymes or hormones are changed in response to exposure to noise waves.[6]-[11]

Nowadays, ultrasound has seen development not only as a diagnostic imaging modality but as a therapeutic modality in which energy is deposited in tissue to induce various biological effects.

In contrast to our finding, there are studies showing that ultra sound waves may have improving effects on some tissues. [13] However, further research are needed to clarify the effects of ultra sound waves on body organs or tissues at cellular and molecular level.

\section{CONCLUSION}

We have shown that exposure to ultra wave sounds results in decreased serum levels of SGPT indicating that exposure to ultra wave sounds particularly for a long period of time may adversely influence heart and/or liver function or structure and/or other tissues.

\section{ACKNOWLEDGMENT}

We appreciate all who helped us to exert the present study.

\section{REFERENCES}

[1] Almo SC, Smith DL, Danishefsky AT, Ringe D. The structural basis for the altered substrate specificity of the R292D active site mutant of aspartateaminotransferase from E. coli. Protein Eng. 1994 Mar;7(3):405-12. http://dx.doi.org/10.1093/protein/7.3.405

[2] McPhalen CA, Vincent MG, Jansonius JN. X-ray structure refinement and comparison of three forms of mitochondrial aspartate aminotransferase. J Mol Biol. 1992 May 20;225(2):495-517.

[3] Muriana FJ, Alvarez-Ossorio MC, Relimpio AM. Purification and characterization of aspartate aminotransferase from the halophile archeaebacterium Haloferaxmediterranei. Biochem J. 1991 Aug 15;278 ( Pt 1):149-54. http://dx.doi.org/10.1042/bj2780149

[4] Hayashi H, Wada H, Yoshimura T, Esaki N, Soda K. Recent topics in pyridoxal 5'-phosphate enzyme studies. Annu Rev Biochem. 1990;59:87-110. http://dx.doi.org/10.1146/annurev.bi.59.070190.000511

[5] Wang CS, Chang TT, Yao WJ, Wang ST, Chou P. Impact of increasing alanine aminotransferase levels within normal range on incident diabetes. J Formos Med Assoc. 2012 Apr;111(4):201-8. http://dx.doi.org/10.1016/j.jfma.2011.04.004

[6] Zawilla N, Shaker D, Abdelaal A, Aref W. Angiotensin-converting enzyme gene polymorphisms and hypertension in occupational noise exposure in Egypt. Int J Occup Environ Health. 2014 Jul-Sep;20(3):194-206. http://dx.doi.org/10.1179/2049396714Y.0000000067

[7] Monsefi M, Bahoddini A, Nazemi S, Dehghani GA. Effects of Noise Exposure on the Volume of Adrenal Gland and Serum Level s of Cortisol in Rat . Iran J Med Sci March 2006; 31 (1): 5.

[8] Wysocki LE, Dittami JP, Ladich F. Ship noise and cortisol secretion in European freshwater fishes. Biol Conserve. 2006; 128:501-8. http://dx.doi.org/10.1016/j.biocon.2005.10.020

[9] Ersoy A, Koc ER, Sahin S, Duzgun U, Acar B, Ilhan A. Possible effects of rosuvastatin on noise-induced oxidative stress in rat brain. Noise Health. 2014 Jan-Feb;16(68):18-25. http://dx.doi.org/10.4103/1463-1741.127849

[10] Ravindran R, Rathinasamy SD, Samson J, Senthilvelan M Noise-stress-induced brain neurotransmitter changes and the effect of Ocimum sanctum (Linn) treatment in albino rats. J Pharmacol Sci. 2005 Aug;98(4):354-60. http://dx.doi.org/10.1254/jphs.FP0050127

[11] Seifirad S, Farzampour S, Nourbakhsh M, Amoli MM, Razzaghy-Azar M, Larijani B. Effects of extremely low frequency electromagnetic fields on paraoxonase serum activity and lipid peroxidationmetabolit-es in rat. J Diabetes Metab Disord. 2014 Aug 13;13(1):85.

http://dx.doi.org/10.1186/s40200-014-0085-2

[12] Ghanbari M, Mortazavi SB, Khavanin A, Khazaei M. The Effects of Cell Phone Waves (900 MHz-GSM Band) on Sperm Parameters and Total Antioxidant Capacity in Rats. Int J Fertil Steril. 2013 Apr;7(1):21-8.

[13] Alexander LD, Gilman DR, Brown DR, Brown JL, Houghton PE. Exposure to low amounts of ultrasound energy does not improve soft tissue shoulder pathology: a systematic review. Phys Ther.2010;90:14-25.

http://dx.doi.org/10.2522/ptj.20080272 